\title{
No Statistic Correlation between Superoxide Dismutase and Peroxidase Activities and Aluminum-Induced Lipid Peroxidation in Maize, Implying Limited Roles of Both Enzymes in Prevention against Aluminum-Induced Lipid Peroxidation
}

\author{
Liang Wang ${ }^{1,2}$ Jian-Yu Zhao, ${ }^{1,2}$, San-Min Wu ${ }^{1,2}$, Jiang-Long Pan ${ }^{1,2}$, Zhang-Bao Huang ${ }^{1}$ Zi-Kai Wu ${ }^{3}$, \\ Xian-Wei Fan ${ }^{1,2}$, You-Zhi $\mathrm{Li}^{1,2}$
}

${ }^{1}$ State Key Laboratory for Conservation and Utilization of Subtropical Agro-bioresources, Nanning, China; ${ }^{2}$ College of Life Science
and Technology, Nanning, China; ${ }^{3}$ Agricultural College, Guangxi University, Nanning, China. Email: liyouzhigxu@163.com

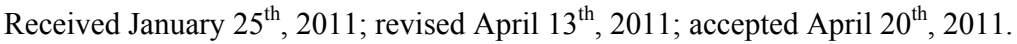

\begin{abstract}
Changes of and correlation among root tolerance index (RTI), root Aluminum (Al) content, root/shoot ratio (RSR), root malondialdehyde (MDA) content, and Superoxide dismutase (SOD) and peroxidase (POD) isoforms of maize YQ 7-96 were investigated under $\mathrm{Al}$ stress and removal of the stress (RS). Consequently, Al stress led to significant decreases in RTI, RSR, SOD and POD activities, but resulted in significant increase in root MDA and, Al accumulation in the tissues; Root SOD and POD activities did not correlate with Al and MDA contents in roots; The activities of SOD and POD were much lower in roots than in leaves, and some isoforms were differentially expressed in a tissue-specific manner. It could be concluded that 1) Al stress can lead to lipid peroxidation; 2) there is a larger POD family composed of different $P O D$ isoforms, some of which are of tissue-specific expression and play different roles in detoxification of Al in maize; 3) for POD isoforms, POD 2 is root-specific. POD 6 and POD 7 are all leaf-specific, POD 5 is not only root-specific but also RS-responsive; 4) high sensitivity of maize to Al is associated in part with much lower activities of both SOD and POD in roots; and 5) more importantly, both SOD and POD are therefore hinted to be not key players in prevention against Al-induced lipid peroxidation.
\end{abstract}

Keywords: Al Toxicity, Antioxidant Enzyme, Antioxidation, Lipid Degradation, Plant

\section{Introduction}

Aluminum (Al) toxicity is one of major environmental factors that constrain crop production and quality in acid soil. Acid soil accounts for $30 \%-40 \%$ of the world's arable lands [1] and for $21 \%$ of the arable lands in China [2]. Al toxicity can make a notable impact on plants, including inhibition of plant root elongation and excessive accumulation of superoxide radicals such as $\mathrm{O}_{2}^{-}$at the cell level [3]. So far, intensive efforts have been made to understand Al-induced peroxidation in plants [4-8]. The excessively accumulated superoxide radicals can induce degradation of many cell constituents such as membrane lipid, protein and DNA [3]. Membrane lipid is one of major constituents forming the skeleton of cell membranes. Degradation of membrane lipid results in loss of integrity of cell membranes. The integrity of cell membranes is very critical in many biochemical reactions in cells [9-11]. In plants, mechanisms for detoxification of $\mathrm{Al}$ include external avoidance that prevents uptake of $\mathrm{Al}$ into plant roots as well as internal tolerance that detoxifies Al internally $[1,12]$. Internal tolerance depends partially on many antioxidant enzymes, such as superoxide dismutase (SOD) and peroxidase (POD) [11,13-15]. SOD and POD constitute the first line of defence against 
reactive oxygen species (ROS) under the stress [16], and their activity and amounts are usually used as an indicator of $\mathrm{Al}$ tolerance in plants since they were found to have higher activity in the Al-tolerant plants than in the Al-sensitive plants [17].

Maize (Zea mays L.) is more sensitive to $\mathrm{Al}$ toxicity than other cereals [18]. Increased activities of SOD and POD were observed in some maize lines exposed to elevated Al concentrations [13]. However, Al-induced peroxidation of lipid in maize is still conflicting. For example, Boscoloa et al. [13] found that Al treatment did not induce lipid peroxidation in both sensitive and tolerant maize lines. However, Giannakoula et al. [11] indicated that $\mathrm{Al}$ treatment could trigger lipid peroxidation in the sensitive maize line. In addition, it is unknown that whether some tissue-specific SOD and POD isoforms in maize response to Al stress exist. Therefore, further researches such as statistic analysis of correlation among the data are needed to have an insight into roles of SOD and $\mathrm{POD}$ in prevention against $\mathrm{Al}$-induced peroxidation of lipid in maize.

YQ 7-96 is a maize inbred line of moderate Al tolerance as well as a short anthesis-silking interval of $0-1$ day. This study focused on the relationship of SOD and POD activities with lipid degradation in this maize line exposed to Al to clarify roles of these two enzymes in preventing Al-induced lipid peroxidation.

\section{Materials and Methods}

\subsection{Plant Culture}

The maize inbred line YQ 7-96 was used in this study, which was bred by Professor Zi-Kai Wu from our research group. Fully mature maize seeds of the same size were soaked for $12 \mathrm{~h}$ at $28^{\circ} \mathrm{C}$ in distilled water, surface-sterilized for $2 \mathrm{~min}$ in $75 \%(\mathrm{v} / \mathrm{v})$ ethanol, and then fully rinsed with sterile water. The sterilized seeds were germinated at $28^{\circ} \mathrm{C}$ in sand moistened with sterile water. The maize seedlings were trimmed for removal of residual endosperms, and mounted for growing in the lattice of the plastic container $(75 \times 40 \times 25 \mathrm{~cm})$ containing 12 L of original Hoagland nutrient solution [19]. Before three-leaf stage, the nutrient solution was vigorously aerated for $15 \mathrm{~min}$ every $1 \mathrm{~h}$; $\mathrm{pH}$ of the solution was adjusted every day to $7 \pm 0.2$. The seedlings were transferred at three-leaf stage for $\mathrm{Al}$ stress treatment into the nutrient solution with $\mathrm{pH} 4.5 \pm 0.2$ and containing 0.5 $\mathrm{mM} \mathrm{AlCl}{ }_{3} \cdot 7 \mathrm{H}_{2} \mathrm{O}$, where toxic $\mathrm{Al}^{3+}$ concentration was estimated to be $48 \mu \mathrm{M}$ by using the Geochem 2.0 software [20]. Following $72 \mathrm{~h}$ of Al stress, the stressed seedlings were treated for another $48 \mathrm{~h}$ by removal of the stress (RS) in the nutrient solution without $\mathrm{AlCl}_{3} \cdot 7 \mathrm{H}_{2} \mathrm{O}$. The control was in parallel conducted in the nutrient solution without $\mathrm{AlCl}_{3} \cdot 7 \mathrm{H}_{2} \mathrm{O}$. All the experiments were conducted at $25^{\circ} \mathrm{C}$ under a $12 \mathrm{~h}$ photoperiod $(120$ $\mu \mathrm{mol} \cdot \mathrm{m}^{-2} \cdot \mathrm{s}^{-1}$ ) in a growth chamber with $60 \%-80 \%$ relative humidity. The nutrient solution was renewed once every 3 days. The treatment duration was in detail indicated in the text.

\subsection{Plant Growth Assay}

Root length from the node between roots and stems down to the tips of taproots was measured at $10 \mathrm{a} . \mathrm{m}$. to obtain root elongation (RE) per day. Root growth under $\mathrm{Al}$ was expressed in root tolerance index (RTI, \%). RTI was calculated as the formula:

$\operatorname{RTI}(\%)=\left(\mathrm{RE}_{\mathrm{Al} \text { stress }} / \mathrm{RE}_{\text {Control }}\right) \times 100$.

For assay of root/shoot ratio (RSR), the seedlings were then immediately oven-dried for $1 \mathrm{~h}$ at $100^{\circ} \mathrm{C}$ and then dried for $8 \mathrm{~h}$ at $70^{\circ} \mathrm{C}$. The dried seedlings were separated into two parts of roots and shoots, which were separately weighed. The RSR was calculated as the formula: RSR = dry weight (DW) of roots/DW of shoots.

\subsection{Assay of Al Content}

$\mathrm{Al}$ content in plant tissues was assayed as the method described by He and Liang [21] but with slight modification. Briefly, $0.1 \mathrm{~g}$ of dried tissues was digested for $24 \mathrm{~h}$ in $1.5 \mathrm{~mL}$ of $2 \mathrm{M} \mathrm{HNO}_{3}$ solution; The resulting hydrolyzate was diluted 20 times with deionized water; An aliquot $(1 \mathrm{~mL})$ of the diluted solution was immediately transferred into a tube, and then the following reactants were sequentially added to the tube: $1 \mathrm{~mL}$ of $0.1 \mathrm{M}$ $\mathrm{HNO}_{3}$ solution, $2 \mathrm{~mL}$ of $5 \mathrm{mM}$ cetyltrimethyl ammonium bromide solution, $2 \mathrm{~mL}$ of $50 \mathrm{mM}$ EDTA-Zn solution, 2 $\mathrm{mL}$ of the solution with $0.05 \%(\mathrm{w} / \mathrm{v})$ chromazurol-S, and $4 \mathrm{~mL}$ of $40 \%(\mathrm{w} / \mathrm{v})$ ammonioformaldehyde solution; The solution was then diluted up to $25 \mathrm{~mL}$ with deionized water, placed for $20 \mathrm{~min}$ at $25^{\circ} \mathrm{C}$, and then assayed for absorbance at $635 \mathrm{~nm}$ by using the 722 spectrophotometer (Shanghai Leng Guang Technology Co. Ltd. China).

\subsection{Assay of Specific Activities SOD and POD}

The fresh tissues of roots and leaves were rinsed with sterile distilled water and then immediately frozen in liquid nitrogen. The tissues $(0.5 \mathrm{~g})$ were ground into the homogenate in $10 \mathrm{~mL}$ of pre-cooling buffer solution of $\mathrm{pH} 7.4$ and composed of $1 \mathrm{mM}$ EDTA and $50 \mathrm{mM}$ $\mathrm{H}_{3} \mathrm{PO}_{4}$. The homogenate was centrifuged for $20 \mathrm{~min}$ at $16,000 \times g$ at $4^{\circ} \mathrm{C}$. The supernate was collected and stored at $-80^{\circ} \mathrm{C}$ as tissue extract for further use.

Specific activity of SOD was determined as p-nitro 
blue tetrazolium chloride (NBT) photoreduction [22]. In brief, $0.1 \mathrm{~mL}$ of the tissue extract was added to a glass tube containing the solution of $\mathrm{pH} 7.4$ and composed of the reagents of $1.5 \mathrm{~mL}$ of $50 \mathrm{mM} \mathrm{H}_{3} \mathrm{PO}_{4}, 0.3 \mathrm{~mL}$ of 13 $\mathrm{mM}$ methionine, $0.3 \mathrm{~mL}$ of $75 \mu \mathrm{M}$ NBT, $0.3 \mathrm{~mL}$ of 10 $\mu \mathrm{M}$ EDTA- $\mathrm{Na}_{2}, 0.3 \mathrm{~mL}$ of $2 \mu \mathrm{M}$ riboflavin, and $0.5 \mathrm{~mL}$ sterile deionized water. The tube was positioned $30 \mathrm{~cm}$ away from a fluorescent lamp with 3098 Lux units for 20 $\min$ at $25^{\circ} \mathrm{C}$. The resulting reaction mixture in the tube was then analyzed for absorbance at $560 \mathrm{~nm}$. One unit of SOD is defined by the amount of enzyme that inhibits NBT photoreduction by $50 \%$ [23]. The specific activity of enzyme was expressed as unit $\mathrm{mg}^{-1}$ protein [24].

Specific activity of POD was assayed following the guaiacol oxidation method [22]. Briefly, $20 \mathrm{~mL}$ of the tissue extract were reacted with $3 \mathrm{~mL}$ solution containing $1 \% \mathrm{H}_{2} \mathrm{O}_{2}(\mathrm{v} / \mathrm{v}), 0.5 \%$ (w/v) guaiacol and $50 \mathrm{mM} \mathrm{H}_{3} \mathrm{PO}_{4}$. The reaction mixture was then analyzed for absorbance at $470 \mathrm{~nm}$. One unit of the enzyme was defined as an optical density value of 0.01 . The specific activity of the enzyme was given as unit $\mathrm{min}^{-1} \cdot \mathrm{mg}^{-1}$ protein.

\subsection{Analysis of Isoforms of SOD and POD}

The isoforms of enzymes were analyzed following nondenaturing polyacrylamide gel electrophoresis (PAGE) method [25]. For PAGE, $25 \mathrm{~mL}$ of the tissue extract per gel slot were loaded. The electrophoresis was conducted for $15 \mathrm{~min}$ at $70 \mathrm{v}$ and then for $2 \mathrm{~h}$ at $220 \mathrm{v}$.

For SOD isoforms, the gel was stained for $20 \mathrm{~min}$ in dark in the solution composed of $0.24 \mathrm{mM} \mathrm{NBT}$ and 50

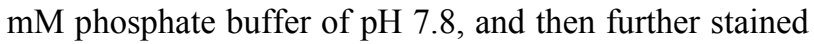
for $15 \mathrm{~min}$ in the solution containing $33.2 \mu \mathrm{M}$ riboflavin, $0.2 \%(\mathrm{v} / \mathrm{v})$ tetramethylethylenediamine and $50 \mathrm{mM}$ phosphate buffer of $\mathrm{pH}$ 7.8. Following staining, the gel was transferred into the phosphate buffer containing $1 \mathrm{mM}$ EDTA and positioned $30 \mathrm{~cm}$ away from the light source of 3000 Lux units at room temperature until colored. The SOD isoforms were distinguished by their sensitivity to 2 $\mathrm{mM} \mathrm{KCN}$ or $5 \mathrm{mM} \mathrm{H}_{2} \mathrm{O}_{2}$ [25].

Analysis of POD isoform followed the method in the literature [26] but with modification. In brief, following PAGE, the gel was soaked for coloring for $5 \mathrm{~min}$ at room temperature in the solution containing $1 \mathrm{mM}$ benzidine and $0.2 \% \mathrm{H}_{2} \mathrm{O}_{2}$.

Following coloring, the gel was analyzed by using the Gel-Pro analyzer software (Media Cybernetics)

\subsection{Assay of Root Malondialdehyde (MDA)}

Root MDA content was assayed as thiobarbituric acid (TBA) method [22]. Briefly, an aliquot $(1 \mathrm{~mL})$ of root extract was mixed with $2 \mathrm{~mL}$ of the solution composed of $0.6 \%$ TBA and $10 \%$ trichloracetic acid. The reaction mixture was incubated for $30 \mathrm{~min}$ in water of $100^{\circ} \mathrm{C}$, quickly cooled up to $0^{\circ} \mathrm{C}$ in ice water, and then centrifuged for $5 \mathrm{~min}$ at $11,600 \times \mathrm{g}$ at $4^{\circ} \mathrm{C}$. The supernate was analyzed at $532 \mathrm{~nm}\left(\mathrm{~A}_{523}\right)$ and $450 \mathrm{~nm}\left(\mathrm{~A}_{450}\right)$, respectively. The MDA content was calculated as the formula: MDA $\left(\mu \mathrm{m} \cdot \mathrm{g}^{-1}\right.$ fresh weight $)$ $=\left[\left(6.45 \times \mathrm{A}_{523}-0.56 \times \mathrm{A}_{450}\right) \times 10 \mathrm{~mL}\right] / 0.5$.

\subsection{Statistical Data Analysis}

The statistical data analysis was conducted with the software SPSS 13.0 (http://www.spss.com/).

\section{Results}

\subsection{RTI and Root Al Content of Maize Inbred Line YQ 7-96}

RTI of maize YQ 7-96 seedlings sharply decreased with Al stress, dropped to $42 \%$ at $72 \mathrm{~h}$, but was up to $79 \%$ after a $48 \mathrm{~h}$ treatment of RS (Figure 1), agreeing with previous studies that $\mathrm{Al}$ stress can inhibit plant root elongation [9,13,27-31].

$\mathrm{Al}$ content in roots of the seedlings increased with $\mathrm{Al}$ stress and reached $752 \mu \mathrm{g} \cdot \mathrm{g}^{-1} \mathrm{DW}$ at $72 \mathrm{~h}$, decreased to $622 \mu \mathrm{g} \cdot \mathrm{g}^{-1} \mathrm{DW}$ after a $48 \mathrm{~h}$ RS treatment (Figure 1).

The above results indicated that in maize YQ 7-96 Al

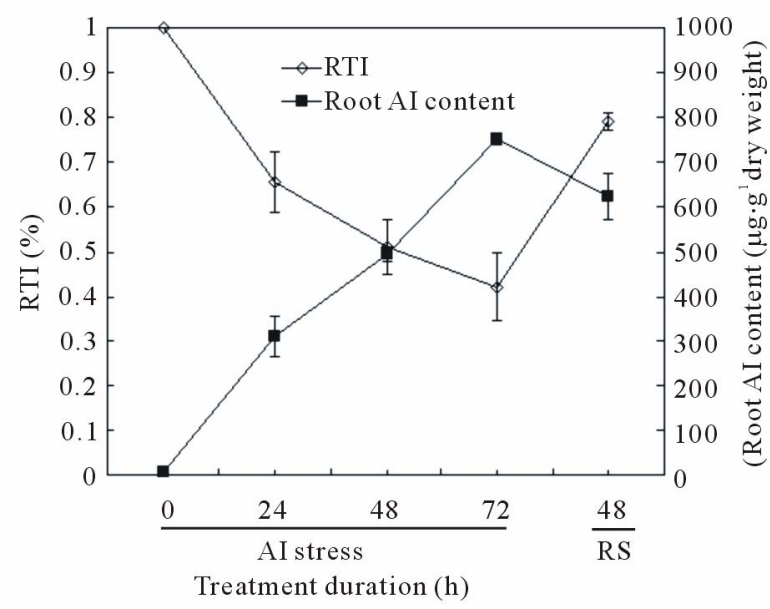

Figure 1. Changes in RTI and Al content in maize inbred line YQ 7-96 roots with Al stress. Treatments of maize seedlings began at the three-leaf stage in the original Hoagland nutrient solution with or without addition of $\mathrm{AlCl}_{3} \cdot 7 \mathrm{H}_{2} \mathrm{O}$. During each treatment period, lengths from the node between roots and stems down to the tips of taproots were measured at 10 a.m. every day. RS was conducted on 72-h-stressed seedlings in the nutrient solution without $\mathrm{AlCl}_{3} \cdot 7 \mathrm{H}_{2} \mathrm{O}$. Each datum is the mean $\pm \mathrm{SD}(\mathrm{n}=10$ - 15 for RTI; $n=3$ - 5 for Al content). RE, Root elongation. RS, Removal of the stress. RTI, Root tolerance index. 
stress-caused inhibition of root elongation was coupled with increased $\mathrm{Al}$ content in the roots, consisting with previous results observed in Al-stressed maize [13,28,29,31].

\subsection{RSR of Maize YQ 7-96}

The RSR of Al-stressed maize seedlings significantly declined in comparison with that of control seedlings. After the $48 \mathrm{~h}$ RS treatment, RSR obviously increased but was still lower than that of control seedlings at the same growth stage (Figure 2). The results underpinned the previous conclusion that $\mathrm{Al}$ stress effect on plants lies mainly in inhibiting the root growth $[9,15]$.

\subsection{SOD and POD Activities}

Change in SOD and POD activities is a common feature of higher plants in response to abiotic stresses $[3,32]$. Specific activities of SOD and POD significantly $(p<$ 0.05 ) decreased in Al-stressed YQ 7-96 roots in comparison with those in control seedlings (Figure 3). However, enzyme activities in the stressed roots fluctuated with the stress, which decreased at $24 \mathrm{~h}$, increased at $48 \mathrm{~h}$ and then significantly dropped at $72 \mathrm{~h}$. After the $48 \mathrm{~h}$ RS treatment, specific activities of the enzymes in stressed roots obviously increased in comparison with those in 72-h-stressed seedlings (Figure 3). Alteration in enzymes' activities during $\mathrm{Al}$ stress was similar to results in Al-stressed emerging roots of barley seeds [6], but differed from results in both Al-tolerant and Al-sensitive

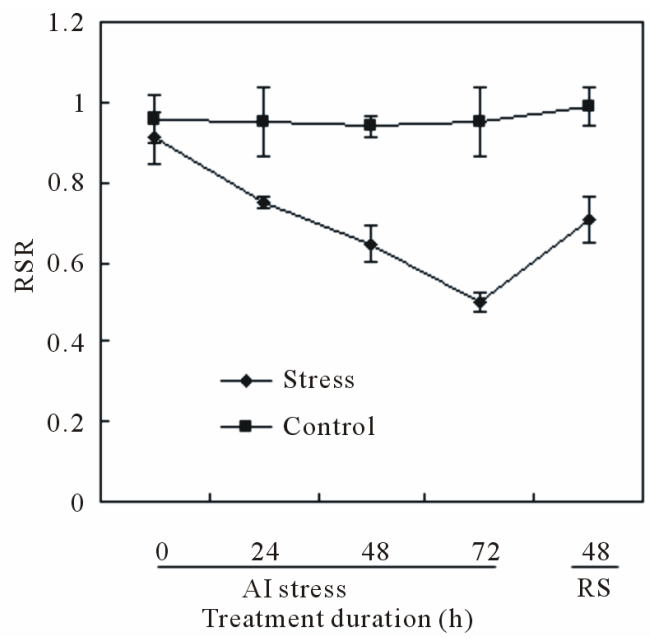

Figure 2. Change in RSR of maize inbred line YQ 7-96 with Al stress. Treatments of maize seedlings began at the three-leaf stage. RS was conducted on 72-h-stressed seedlings in the nutrient solution without $\mathrm{AlCl}_{3} \cdot 7 \mathrm{H}_{2} \mathrm{O}$. The harvested seedlings were immediately dried, and the roots and leaves of the dried seedlings were weighed, respectively. Each datum is the mean $\pm S D(n=10$ - 15). RS, Removal of the stress. RSR, root/shoot ratio.

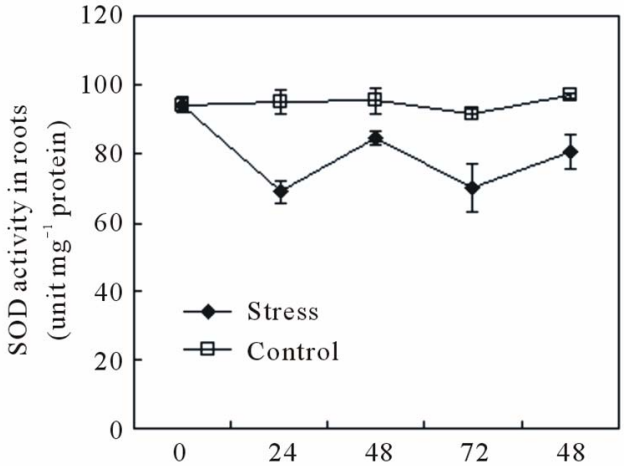

(a)

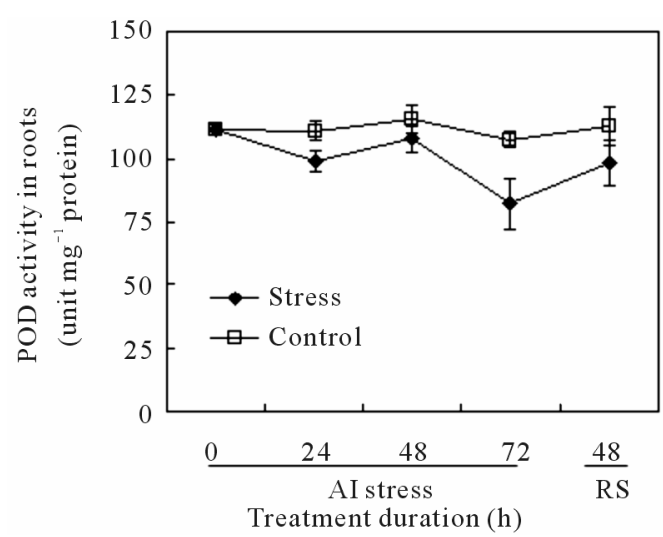

(b)

Figure 3. Changes in activities of SOD and POD in maize inbred line YQ 7-96 roots with treatment time. (a): Specific activity of SOD. (b): Specific activity of POD. Treatments of maize seedlings began at the three-leaf stage. RS was conducted on 72-h-stressed seedlings in the nutrient solution without addition of $\mathrm{AlCl}_{3} \cdot 7 \mathrm{H}_{2} \mathrm{O}$. Specific activities of SOD and POD were determined as methods described by Tang [22]. SOD was assayed based on inhibition of NBT photoreduction; POD was assayed following the guaiacol oxidation method. Measurement of enzyme activity was biologically repeated, one seedling was designed for one biological repeat. Each datum is mean \pm SD $(n=3)$. NBT, p-nitro blue tetrazolium chloride. RS, Removal of the stress.

maize lines [13]. Anyway, enzyme's activities correlated with declines in root elongation (Figure 1) as well as RSR (Figure 2).

SOD isoforms were not detectable in both control and Al-stressed roots (Figure 4(a)). Four POD isoforms were detected in roots, which were named POD 1, POD 2, POD 3, and POD 4 according to migration rate on the gel (Figure 4(b)). Based on analysis of Gel-Pro analyzer software (data not shown) POD 1 and POD 2 activities significantly decreased, but POD 3 and POD 4 activities significantly increased in Al-stressed roots in comparison with control roots; However, total activity of detected 

Lipid Peroxidation in Maize, Implying Limited Roles of Both Enzymes in Prevention against Aluminum-Induced Lipid Peroxidation

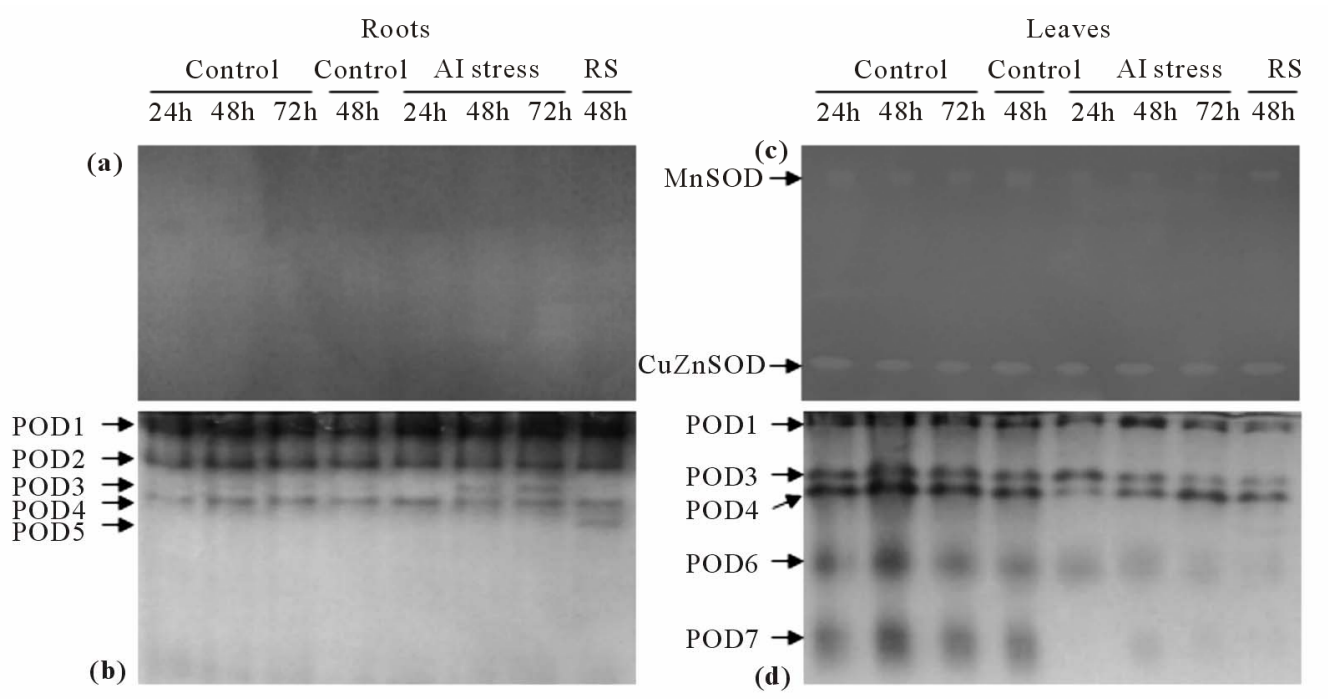

Figure 4. Time-course analysis of isoforms of SOD and POD in maize inbred line YQ 7-96. (a): Activities of root SOD isoforms; (b): Activities of root POD isoforms; (c): Activities of leaf SOD; (d): Activities of leaf POD; Analyses of SOD and POD isoforms were based on non-denaturing PAGE. SOD isoforms were distinguished by their sensitivity to $2 \mathrm{mM} \mathrm{KCN} \mathrm{or} 5 \mathrm{mM}$ $\mathrm{H}_{2} \mathrm{O}_{2}$ [25]. POD isoforms were analyzed by coloring [26]. Quantitative analysis of enzyme activities was conducted by using the Gel-Pro analyzer software (Media Cybernetics). Three independent experiments were conducted. PAGE, polyacrylamide gel electrophoresis. RS, Removal of the stress.

POD isoforms significantly decreased in Al-stressed roots throughout the stress; Even after RS treatment, total activity of POD isoforms in stressed roots was only $96 \%$ of that in control roots. Interestingly, after RS treatment, a novel POD isoform, POD 5, occurred in Al-stressed roots (Figure 4(b)), suggesting that it is an enzyme of RS-specific response.

Two SOD isoforms, MnSOD and CuZnSOD, were observed in maize leaves (Figure 4(c)). MnSOD activity decreased by about $50 \%$ when compared to that in control leaves. CuZnSOD activity significantly declined at $24 \mathrm{~h}$, increased at $48 \mathrm{~h}$, and decreased again at $72 \mathrm{~h}$ (Figure 4(c)). Interestingly, the profile of POD isoforms in leaves (Figure 4(d)) differed from that in roots (Figure 4(b)). RS-responsive POD 5 and Al stress-responsive POD 2 in roots (Figure 4(b)) did not appear in leaves (Figure 4(d)). Leaf-specific POD isoforms included POD 6 and POD 7 (Figure 4(d)). In stressed leaves, POD 1 activity significantly increased at $48 \mathrm{~h}$ and decreased at $72 \mathrm{~h}$; POD 3 activity increased at 24 and $48 \mathrm{~h}$, but decreased at $72 \mathrm{~h}$; POD 4 activity decreased at 24 and $48 \mathrm{~h}$; Activities of both POD 6 and POD 7 decreased throughout the stress.

\subsection{MDA Content in YQ 7-96 Roots}

MDA content in maize YQ 7-96 roots was analyzed because MDA is an indicator as lipid degradation $[3,11]$.
As a result, MDA content in stressed roots significantly $(p<0.05)$ increased upon Al stress; After RS treatment, MDA content in roots of seedlings stressed for $72 \mathrm{~h}$ significantly decreased in comparison with that in roots of the seedlings before RS treatment, but it was still higher than that in control roots at the same stage (Figure 5). All these results suggest that lipid degradation occurred during Al stress, solidifying a previous viewpoint that lipid is an important target for Al toxicity [33].

\subsection{Comprehensive Analysis of the Data}

To conclude whether there was a correlation between the data from stressed roots, a comprehensive statistic analysis of the data was conducted by suing the software SPSS 13.0 (Table 1). In stressed roots, Al content correlated negatively with both RTI and RSR but positively with MDA content. Al content did not show significant correlation with changes in both SOD and POD activities. Both RTI and RSR had a significant negative correlation with root MDA content. Taken together, it can be at least partly suggested that that growth of maize seedlings when exposed to $\mathrm{Al}$ depends on the integrity of cell membranes.

\section{Discussion}

Mechanisms of plant $\mathrm{Al}$ tolerance include prevention of $\mathrm{Al}$ uptake, and detoxification of internal $\mathrm{Al}$ in the cell [12]. Inhibition of root elongation of maize inbred line 


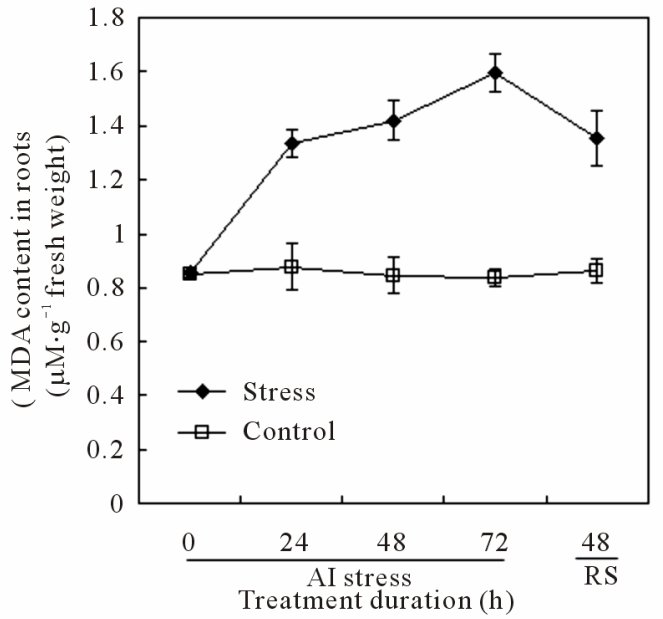

Figure 5. Change in MDA content in maize inbred line YQ 7-96 roots with treatment time. Treatments of maize seedlings began at the three-leaf stage. RS was conducted on 72-h-stressed seedlings in the nutrient solution without addition of $\mathrm{AlCl}_{3} \cdot 7 \mathrm{H}_{2} \mathrm{O}$. Root MDA was assayed by using TBA method [22]. Measurement of enzyme activity was biologically repeated, one seedling were designed for one biological repeat. The presented datum for each time point is the mean \pm SD $(n=5)$. MDA, malondialdehyde. RS, Removal of the stress. TBA, Thiobarbituric acid.

YQ 7-96 grown in the presence of $\mathrm{Al}$ was likely due to loss of extensibility of the root cell wall [30] because of degradation of membrane lipid (Figure 5). After $48 \mathrm{~h}$ AS treatment, recovery of root elongation (Figure 1) was likely because of decrease in Al bound to cell wall [34]. Even if RS treatment time was extended, root elongation of the stressed seedlings could not reach the control level at the same growth stage (data not shown) mainly because Al-affected roots are inefficient in absorbing both nutrients and water [9].

Activities of plant SOD and POD were found to vary greatly during $\mathrm{Al}$ stress. For example, activities of both the enzymes changed in an opposite manner in Alstressed rice: SOD activity decreased while POD activity increased only after long-term treatment [35]. Also in rice, Al-induced increase in POD activity was found in roots of the Al-resistant cultivar, but increment of the enzyme activity was only half of the Al-sensitive cultivar [26]. Activities of SOD and POD indeed increased in the root tips of soybean exposed to Al [4]. Diverse patterns of SOD and POD activities were also found in different maize lines grown under Al. For example, Boscolo et al. [13] found that changes in changes in activities of both SOD and POD were the same, either transient increase at the later stress in the Al-sensitive maize or little change over Al stress in Al-tolerant maize line. More recently, Giannakoula et al. [36] found that Al stress resulted in increased activities of SOD and POD in the Al-tolerant maize line but not in the Al-sensitive line. Unlike these results, our results clearly indicated that there was no statistic correlation between changes in SOD and POD specific activities, RTI, and Al accumulation in the stressed YQ 7-96 roots (Table 1), agreeing with that Al-caused oxidative stress is not the primary cause of maize root growth inhibition [13]. Discrepancy among existing results are maybe associated with that the abiotic stresses are often of species or location specific [37].

Both SOD and POD play role in antioxidation [38-40]. According to growth phenotype (Figures 1 and 2), decreased activities of both enzymes at $24 \mathrm{~h}$ of the stress were likely due to quick decline in cell viability because even exposed for short-term (5 $\mathrm{min}$ ) to Al maize root cell division can also be inhibited [18]. Increased activities of the enzymes at $48 \mathrm{~h}$ of the stress were likely associated with enhancement of Al-induced oxidative stress. Decreased activities of the enzymes after long- term stress treatment (Figure 3) may be ascribed to overproduction of ROS and/or a build-up of a protection against oxidative damage [25], and partially to cell damage and death

Table 1. Analysis of correlation between the data from Al-stressed YQ 7-96 roots exposed to Al.

\begin{tabular}{|c|c|c|c|c|c|c|}
\hline Items tested & Root $\mathrm{Al}$ content & RTI & RSR & Root MDA content & Root SOD activity & Root POD activity \\
\hline Root $\mathrm{Al}$ content & 1 & & & & & \\
\hline RTI & $-0.968^{*}$ & 1 & & & & \\
\hline RSR & $-0.997 * *$ & $0.974 *$ & 1 & & & \\
\hline Root MDA content & $0.964 *$ & $-0.992 * *$ & $-0.978 *$ & 1 & & \\
\hline Root SOD activity & -0.653 & 0.710 & 0.708 & -0.788 & 1 & \\
\hline Root POD activity & -0.835 & 0.741 & 0.855 & -0.800 & 0.792 & 1 \\
\hline
\end{tabular}

$* p<0.05 ; * *<0.01$. The analysis was based on the full set of raw data from all Al-treated time points instead of at one time point. The figures indicate $r^{2}$ values between two sets of analyzed data. Analysis was conducted by using the software SPSS 13.0 (http://www.spss.com/). The $r^{2}$ value of either $p<0.05$ or $p$ $<0.01$ means that there is a significant correlation between the data. 
due to overall expression of $\mathrm{Al}$ toxicity and $\mathrm{Al}$-induced secondary stress such as drought [8].

The total activities of isoforms of both SOD and POD were much lower in maize roots than in maize leaves (Figure 4). No activities of SOD were detected by gel analysis in maize roots grown under control and $\mathrm{Al}$ stress conditions (Figures 4(a) and (c)). One of the obvious reasons for this is that the enzyme is of much lower activity in roots (Figure 4(a)) than that in leaves (Figure 4(c)). Anyway, high sensitivity of maize roots to $\mathrm{Al}$ [18] may be explained at least partially by low SOD activity as indicated by maize inbred line YQ 7-96. It is reported in sunflower that different POD isoforms have different functions, of which some work directly as oxygen species scavenger and others could play a role in polyphenols metabolism to increase the antioxidant capacity or cross-linking UV-absorbing phenolics [37]. Occurrence of POD 5 only in stressed roots after RS (Figure 4(b)) is probably associated with requirement for damage repair during RS treatment. All these results strongly suggest that there exists a larger POD gene family composed of different isoforms in maize, which are differentially expressed in the tissues of Al-stressed maize and have functional difference in detoxification of $\mathrm{Al}$.

Although activities of different isoforms of SOD and POD varied greatly, the total activities of both the enzymes changed in the same manner with Al stress (Figure 3). This reflects synergistic roles of SOD and POD in antioxidation. Usually, the superoxide radical $\left(\mathrm{O}_{2}^{-}\right)$is first degraded by SOD into $\mathrm{O}_{2}$ and $\mathrm{H}_{2} \mathrm{O}_{2}$; Resulting $\mathrm{H}_{2} \mathrm{O}_{2}$ is then degraded by POD [13].

Al stress-caused peroxidation of lipid has been found in other plant species such as soybean [4] and rice [5,35], but was controversial in maize [11,13,41]. Al stress did lead to lipid peroxidation of the stressed YQ 7-96 roots because of a significant relationship between $\mathrm{Al}$ and MDA contents (Table 1). According to all these results, Al-caused peroxidation of lipid seems to depend greatly on plant genotypes. In maize, one of likely reasons for this is associated with differences between maize genotypes in the negative charge on the cell wall. The negative charge on the cell wall is a major determinant of the initial $\mathrm{Al}$ accumulation [34].

Statistical analysis clearly indicated that MDA content in Al-stressed YQ 7-96 roots did not correlate with activities of root SOD and POD of this maize line (Table 1). This suggests that roles of both the enzymes in prevention of Al-caused peroxidation of lipid are very limited. It has been indicated that Al does not directly result in peroxidation in membrane lipid because $\mathrm{Al}$ is a non-transition metal and cannot catalyze the peroxidation reaction [3]. Al bound to the membranes can directly cause membrane rigidification that can therefore facilitate the iron catalyzed lipid peroxidation in the membrane [42].

Taken together, $\mathrm{Al}$ stress can lead to lipid peroxidation; there is a larger POD family composed of different POD isoforms, some of which are of tissue-specific expression and play different roles in detoxification of $\mathrm{Al}$ in maize; For POD isoforms, POD 2 is root-specific. POD 6 and POD 7 are all leaf-specific, POD 5 is not only root-specific but also RS-responsive; High sensitivity of maize to $\mathrm{Al}$ is in part associated with much lower activities of both SOD and POD in roots; More importantly, both SOD and POD are therefore hinted to be not key players in prevention against Al-induced lipid peroxidation, suggesting that their activity and amounts are not used as a reliable indicator for selection of Al-tolerant maize.

\section{Acknowledgements}

This work was supported by the National Basic Research Program of China No. 2011CB100100, The 948 Program of Introduction of Advanced Science and Technology of International Agriculture from the Ministry of Agriculture of the People's Republic of China (2001-205), the Development Program for Guangxi Science and Technology Research (Guikegong 10100005-4 and 02280196), the Key Laboratory of Ministry of Education for Microbial and Plant Genetic Engineering (Director's grant06-11), and The Opening Project of Guangxi Key Laboratory of Subtropical Bioresource Conservation and Utilization (SB0601).

\section{REFERENCES}

[1] L. V. Kochian, "Cellular Mechanisms of Aluminum Toxicity and Resistance in Plants," Annual Review of Plant Physiology and Plant Molecular Biology, Vol. 46, June 1995, pp. $237-260$. doi:10.1146/annurev.pp.46.060195.001321

[2] C. F. Meng, P. K. Jiang, Z. H. Cao, Q. F. Xu and G. M. Zhou, "Study Progress on Mechanisms of Aluminum Toxicity and Resistance in Plants," Acta Agriculturae Zhejiangensis, Vol. 21, No. 4, July 2009, pp. 411-416.

[3] S. R. Devi, Y. Yamamoto and H. Matsumoto, "An Intracellular Mechanism of Aluminum Tolerance Associated with High Antioxidant Status in Cultured Tobacco Cells," Journal of Inorganic Biochemistry, Vol. 97, No. 1, September 2003, pp. 59-68.

[4] I. Cakmak and W. J. Horst, "Effect of Aluminium on Lipid Peroxidation, Superoxide Dismutase, Catalase, Peroxidase Activities in Root Tips of Soybean (Glycine max L.)," Physiologia Plantarum, Vol. 83, No. 3, November 1991, pp. 463-468. 

Lipid Peroxidation in Maize, Implying Limited Roles of Both Enzymes in Prevention against Aluminum-Induced Lipid Peroxidation

[5] B. Meriga, B. K. Reddy, K. R. Rao L. A. Reddy and P. B. Kishor, "Aluminium-Induced Production of Oxygen Radicals, Lipid Peroxidation and DNA Damage in Seedlings of Rice (Oryza sativa)," Journal of Plant Physiology, Vol. 161, No. 1, January 2004, pp. 63-68. doi:10.1078/0176-1617-01156

[6] L. Tamás, M. Šimonovičová, J. Huttová and I. Mistrík, "Aluminium Stimulated Hydrogen Production of Germinating Barley Seeds," Environmental and Experimental Botany, Vol. 51, No. 3, June 2004, pp. 281-288. doi:10.1016/j.envexpbot.2003.11.007

[7] L. Tamás, S. Budíková, J. Huttová, I. Mistrík, M. Simonovicová and B. Siroká, "Aluminum-Induced Cell Death of Barley-Root Border Cells is Correlated with Peroxidase- and Oxalate Oxidase-Mediated Hydrogen Peroxide Production," Plant Cell Reports, Vol. 24, No. 3, June 2005, pp. 189-194. doi:10.1007/s00299-005-0939-7

[8] L. Tamás, J. Huttová, I. Mistrík, M. Simonovicová and B. Siroká, "Aluminium-Induced Drought and Oxidative Stress in Barley Roots," Journal of Plant Physiology, Vol. 163, No. 7, May 2006, pp. 781-784. doi:10.1016/i.jplph.2005.08.012

[9] T. Mossor-Pietraszewska, "Effect of Aluminium on Plant Growth and Metabolism," Acta Biochimica Poinical, Vol. 48, 2001, pp. 673-686.

[10] R. Chaffai, B. Marzouk and E. El Ferjani, "Aluminum Mediates Compositional Alterations of Polar Lipid Classes in Maize Seedlings," Phytochemistry, Vol. 66, No. 16, August 2005, pp. 1903-1912. doi:10.1016/j.phytochem.2005.06.028

[11] A. Giannakoula, M. Moustakas, P. Mylona, I. Papadakis and T. Yupsanis, "Aluminum Tolerance in Maize is Correlated with Increased Levels of Mineral Nutrients, Carbohydrates and Proline, and Decreased Levels of Lipid Peroxidation and Al Accumulation," Journal of Plant Physiology, Vol. 165, No. 4, 2008, pp. 385-396. doi:10.1016/j.jplph.2007.01.014

[12] Z. Rengel, "Uptake of Aluminium by Plant Cells," New Phytologist, Vol. 134, No. 3, March 1996, pp. 389-406. doi:10.1111/j.1469-8137.1996.tb04356.x

[13] P. R. S. Boscolo, M. Menossi and R. A. Jorge, "Aluminum-Induced Oxidative Stress in Maize," Phytochemistry, Vol. 62, No. 2, January 2003, pp. 181-189. doi:10.1016/S0031-9422(02)00491-0

[14] L. S. Chen, "Physiological Responses and Tolerance of Plant Shoot to Aluminum Toxicity," Journal of Plant Physiology and Molecular Biology, Vol. 32, April 2006, pp. 143-155.

[15] C. Poschenrieder, B. Gunsé, I. Corrales and J. Barceló, "A Glance into Aluminum Toxicity and Resistance in Plants," Science of the Total Environment, Vol. 400, August 2008, pp. 356-368.

[16] S. Veljovic-Jovanovic, B. Kukavica, B. Stevanovic and F. Navari-Izzo, "Senescence- and Drought-Related Changes in Peroxidase and Superoxide Dismutase Isoforms in Leaves of Ramonda Serbica," Journal of Experimental Botany, Vol. 57, No. 8, May 2006, pp. 1759-1768. doi:10.1093/jxb/er1007

[17] É. Darkó, H. Ambrus, É. Stefanovits-Bányai, J. Fodor, F. Bakos and B. Barnabás, "Aluminium Toxicity, Al Tolerance and Oxidative Stress in an Al-Sensitive Wheat Genotype and in Al-Tolerant Lines Developed by in Vitro Microspore Selection," Plant Science, Vol.166, March 2004, pp. 583-591.

[18] S. Doncheva, M. Amenós, C. Poschenrieder and J. Barceló, "Root Cell Patterning: A Primary Target for Aluminium Toxicity in Maize," Journal of Experimental Botany, Vol. 56, No. 414, April 2005, pp. 1213-1220. doi:10.1093/jxb/eri115

[19] D. R. Hoagland and D. I. Arnon, "The Water-Culture Method for Growing Plants Without Soil," Circular 347, University of California, College of Agriculture, Berkeley, 1938.

[20] J. E. Shaff, B. A. Schultz, E. J. Craft, R. T. Clark and L. V. Kochian, "GEOCHEM-EZ: A Chemical Speciation Program with Greater Power and Flexibility," Plant and Soil Journal, Vol. 330, No. 1-2, April 2010, pp. 207-214. doi:10.1007/s11104-009-0193-9

[21] B. He and J. Liang, "Highly Sensitive Spectrophotometric Determination of Aluminium in Plant and Soil Water with Chromazurol S, Cetyltrimethylammonium Bromide and Alcohol," Journal of Guangxi Agricultural University, Vol. 35, 1995, pp.151-155.

[22] Z. C. Tang, "Experimental Guide of Modern Plant Physiology," Science Press, Beijing, 1999, pp. 1-425.

[23] T. Zbigniew and P. Wojciech, "Individual and Combined Effect of Anthracene, Cadmium, and Chloridazone on Growth and Activity of SOD Izoformes in Three Scenedesmus Species," Ecotoxicology and Environmental Safety, Vol. 65, No. 3, November 2006, pp. 323-331. doi:10.1016/j.ecoenv.2005.12.001

[24] R. K. Tewari, P. Kumar and P. N. Sharma, "Morphology and Oxidative Physiology of Sulphur-Deficient Mulberry Plants," Environmental and Experimental Botany, Vol. 68, No. 3, May 2010, pp. 301-308. doi:10.1016/j.envexpbot.2010.01.004

[25] Y. Pan, L. J. Wu and Z. L. Yu, "Effect of Salt and Drought Stress on Antioxidant Enzymes Activities and SOD Isoenzymes of Liquorice (Glycyrrhiza uralensis Fisch)," Plant Growth Regulation, Vol. 49, No. 2-3, September 2006, pp. 157-165. doi:10.1007/s10725-006-9101-y

[26] L. Tamás, J. Huttová and I. Mistrík, "Inhibition of Alinduced Root Elongation and Enhancement of Al-Induced Peroxidase Activity in Al-Sensitive and Al-Resistant Barley Cultivars are Positively Correlated," Plant and Soil, Vol. 250, No. 2, 2003, pp.193-200. doi:10.1023/A:1022863211942

[27] C. H. Goht and Y. Lee, "Aluminum Uptake and Alumi- 
num-Induced Rapid Root Growth Inhibition of Rice Seedlings," Journal of Plant Biology, Vol. 42, June 1999, pp. 151-158.

[28] W. J. Horst, N. Schmohl, M. Kollmeier, F. Balušeka and M. Sivaguru, "Does Aluminium Affect Root Growth of Maize through Interaction with the Cell Wall-Plasma Membrane-Cytoskeleton Continuum?" Plant and Soil, Vol. 215, No. 2, 1999, pp.163-174. doi:10.1023/A:1004439725283

[29] M. Kollmeier, P. Dietrich, C. S. Bauer, W. J. Horst and R. Hedrich, "Aluminum Activates a Citrate-Permeable Anion Channel in the Aluminum-Sensitive Zone of the Maize Root Apex. A Comparison between an Aluminum-Sensitive and an Aluminum-Resistant Cultivar," Plant Physiology, Vol. 126, No. 1, May 2001, pp.397-410. doi:10.1104/pp.126.1.397

[30] J. F. Ma, R. Shen, S. Nagao and E. Tanimoto, "Aluminum Targets Elongating Cells by Reducing Cell Wall Extensibility in Wheat Roots," Plant \& Cell Physiology, Vol. 45, No. 5, May 2004, pp. 583-589. doi:10.1093/pcp/pch060

[31] L. G. Maron, M. Kirst, C. Mao, M. J. Milner, M. Menossi and L. V. Kochian, "Transcriptional Profiling of Aluminum Toxicity and Tolerance Responses in Maize Roots," New Phytologist, Vol. 179, No. 1, April 2008, pp. 116128.doi:10.1111/j.1469-8137.2008.02440.x

[32] J. F. Ma and J. Furukava, "Recent Progress in the Research of External A1 Detoxification in Higher Plants: A Minireview," Journal of Inorgannic Biochemistry, Vol. 97, No. 1, 2003, pp. 46-51. doi:10.1016/S0162-0134(03)00245-9

[33] R. Takabatake and T. Shimmen, "Inhibition of Electrogenesis by Aluminum in Characean Cells," Plant \& Cell Physiology, Vol. 38, 1997, pp.1264-1271.

[34] A. F. Rangel, I. M. Rao and W. J. Horst, "Intracellular Distribution and Binding State of Aluminum in Root Apices of Two Common Bean (Phaseolus Vulgaris) Genotypes in Relation to Al Toxicity," Physiologia Plan- tarum, Vol. 135, No. 2, February 2009, pp. 162-173. doi:10.1111/j.1399-3054.2008.01183.x

[35] M. C. Kuo and C. H. Kao, "Aluminum Effects on Lipid Peroxidation and Antioxidative Enzyme Activities in Rice Leaves," Biologia Plantarum, Vol. 46, No. 1, 2003, pp.149-152. doi:10.1023/A:1022356322373

[36] A. Giannakoula, M. Moustakas, T. Syros and T. Yupsanis, "Aluminum Stress Induces up-Regulation of an Efficient Antioxidant System in the Al-Tolerant Maize Line but Not in the Al-Sensitive Line," Environmental and Experimental Botany, Vol. 67, No. 3, January 2010, pp. 487-494. doi:10.1016/j.envexpbot.2009.07.010

[37] G. G. Yannarelli, S. M. Gallego and M. L. Tomaro, "Effect of UV-B Radiation on the Activity and Isoforms of Enzymes with Peroxidase Activity in Sunflower Cotyledons," Environmental and Experimental Botany, Vol. 56, No. 2, June 2006, pp.174-181. doi:10.1016/j.envexpbot.2005.01.015

[38] J. M. Matés, "Effects of Antioxidant Enzymes in the Molecular Control of Reactive Oxygen Species Toxicology," Toxicology, Vol. 153, November 2000, pp. 83-104.

[39] F. C. Lidon and M. da Graça Barreiro, "An Overview into Aluminium Toxicity in Maize," Bulgarian Journal of Plant Physiology, Vol. 28, 2002, pp. 96-112.

[40] R. Mittler, "Oxidative Stress, Antioxidants and Stress Tolerance," Trends in Plant Science, Vol. 7, No. 9, September 2002, pp. 405-410. doi:10.1016/S1360-1385(02)02312-9

[41] B. Gunsé, C. Poschenrieder and J. Barceló, "Water Transport Properties of Roots and Root Cortical Cells in Proton- and Al-Stressed Maize Varieties," Plant Physiology, Vol. 113, February 1997, pp. 595-602.

[42] Y. Yamamoto, A. Hachiya and H. Matsumoto, "Oxidative Damage to Membranes by a Combination of Aluminum and Iron in Suspension-Cultured Tobacco Cells," Plant \& Cell Physiology, Vol. 38, 1997, pp. 1333-1339. 